\title{
Glycoprotein Biosynthesis in Small Intestine
}

\author{
III. ENZYMATIC BASIS FOR THE DIFFERENCE IN THE \\ ANTIGENICITY OF MUCINS
}

\author{
Young S. Kim and Jose Perdomo \\ From the Gastrointestinal Research Laboratory, Veterans Administration \\ Hospital, San Francisco, California 94121 and the Department of Medicine, \\ University of California School of Medicine, San Francisco, California 94122
}

A B S T R A C T Rat small intestinal mucosa was examined for ability to produce mucins with human blood group $\mathrm{A}, \mathrm{B}$, and $\mathrm{H}$ activity. Blood group activity of the mucins was compared to antigenic activity of red blood cells in individual rats and the enzymatic basis for differences was investigated. Red cells in all the rats examined contained human blood group $A$ and $B$ antigens. All rats synthesized intestinal mucins having $B$ and $H$ antigenic activity but $57 \%$ failed to produce mucins with blood group $A$ activity $\left(A^{-}\right)$; the remaining $43 \%\left(A^{+}\right)$ produced A substance.

The activities of five glycosyltransferases including $\alpha(1 \rightarrow 2)$ fucosyltransferase, the determinant of human secretor status, were measured in the intestine of $\mathrm{A}^{+}$and $A^{-}$rats. Four enzymes were the same in both groups, while the fifth, $N$-acetylgalactosaminyltransferase, was present only in $\mathrm{A}^{+}$rats. The specificity of this latter enzyme, as found in the rat, appeared similar to that in humans, since it catalyzed addition of $N$-acetyl-D-galactosamine only to acceptors which had the $\mathrm{H}$ determinant structure. In the presence of the enzyme, $\mathrm{A}^{-}$mucin could be converted to $\mathrm{A}^{+}$mucin; this was shown both by hemagglutination inhibition and immunoprecipitin studies of the products of incubation of $\mathrm{A}^{-}$mucin with UDP- $N$ acetyl-D-galactosamine and the enzyme.

These studies indicate that the difference between $\mathrm{A}^{+}$ and $\mathrm{A}^{-}$rats is due to the apparent absence of $N$-acetylgalactosaminyltransferase in the intestinal mucosa of $\mathrm{A}^{-}$ rats. These rats may provide experimental models for studies on the effect of $\mathrm{ABO}$ and secretor status on susceptibility to ulceration and carcinogenesis.

Received for publication 20 October 1971 and in revised form 3 January 1971.

\section{INTRODUCTION}

In 1953, Aird and Benthall (1) noted the increased prevalence of gastric carcinoma in blood group A individuals. Since then the connection of blood group status and factors within the gastrointestinal tract has aroused much interest, thought research along these lines has produced little understanding of the mechanisms which might underlies such an association (2-5). Substances having $\mathrm{ABO}$ blood group activity have been described in various human tissues and secretions (6-11). Mainly on the basis of detailed chemical studies on water soluble $\mathrm{ABH}$ substances isolated from ovarian cyst fluid, these antigens have been shown to be macromolecular glycoproteins, each consisting of a polypeptide core with multiple oligosaccharide side chains (12-14). These oligosaccharide side chains, consisting of several sugars such as L-fucose, D-galactose, $N$-acetyl-D-glucosamine, and $N$-acetyl-D-galactosamine, are linked to the polypeptide core primarily through $\mathrm{O}$-glycosidic linkages between the hydroxy groups of serine or threonine and $N$-acetylD-galactosamine. The serological specificities of A or B blood group substances are generally thought to be determined by the presence of terminal $N$-acetyl-D-galactosamine (A) or D-galactose (B) moieties attached to the $\mathrm{H}$ determinant (15-17).

It has been observed that mucus secreted by cells such as those in the submaxillary gland, stomach, and colon of various mammalian species, e.g. rat, pig, monkey (18-21), and dog, ${ }^{1}$ has antigenic properties to that associated with human ABO blood group activity.

Differences have been observed in the ability of gastric mucosa of $\mathrm{A}^{+}$or $\mathrm{A}^{-}$pigs to incorporate $N$-acetylhexosamine, based on the antigenicity of their mucosal

\footnotetext{
${ }^{1}$ Kim, Y. S., and A. M. Bella, Jr. Unpublished observations.
} 
extract (19). Carlson, Iyer, and Mayo (20) and McGuire (21) while studying porcine submaxillary mucins, showed that an enzyme absent in the $\mathrm{A}^{-}$pig could catalyze the transformation of $\mathrm{A}^{-}$submaxillary mucin to a mucin having $\mathrm{A}^{+}$activity. In addition, a number of glycosyltransferases required for the synthesis of mucin were shown to be localized in the microsomal fraction, obtained from the same pooled material (22).

It has been demonstrated in humans that antigenic determinants on red blood cells, may (secretor) or may not (nonsecretor) appear as secreted glycoproteins in glandular tissues in a form determined by the blood group of the individual (23).

The purpose of the present study in rats was to answer the following questions. Do all rats synthesize and secrete intestinal mucins having $\mathrm{A}, \mathrm{B}$, and $\mathrm{H}$ blood group activity in every case? If there are differences among rats in this regard, can the blood group activity of the mucin be correlated with the presence or absence of these antigens on the red blood cells of individual rats? Lastly, what are the biological mechanisms responsible for differences between the blood group activity of the red blood cells and the secreted mucins?

\section{METHODS}

Preparation of microsomes and mucins. Sprague-Dawley albino male rats weighing $150-200 \mathrm{~g}$ were allowed to eat purina chow diet and to drink water ad lib. until they were killed by decapitation. All subsequent procedures were carried out at $4^{\circ} \mathrm{C}$. The entire length of the small intestine was removed immediately, flushed with ice-cold $0.9 \% \mathrm{NaCl}$ solution, everted, and the mucosa scraped. A portion of the mucosal scrapings was used to prepare the aqueous extracts for testing for the presence of human $\mathrm{ABH}$ blood grouplike substances as follows. About $500 \mathrm{mg}$ (wet weight) of the mucosal scrapings were homogenized in 2 volumes of $0.9 \% \mathrm{NaCl}(\mathrm{v} / \mathrm{w})$ in a Potter-Elvehjem tissue homogenizer, and centrifuged at $20,000 \mathrm{~g}$ for $10 \mathrm{~min}$. The supernate was tested for hemagglutination-inhibition.

The remaining material was used to prepare microsomes to be used either as a source of glycosyltransferases or as an exogenous acceptor for these enzymes. The scrapings were homogenized in 4 volumes $(\mathrm{v} / \mathrm{w})$ of $0.25 \mathrm{M}$ sucrose in a Potter-Elvehjem homogenizer. The mucosal homogenate was then processed by the use of the differential centrifugation method to obtain the microsomal pellet (22). The microsomal pellets were resuspended in $0.25 \mathrm{M}$ sucrose

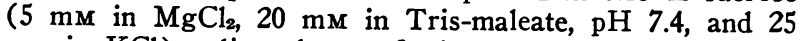
$\mathrm{mM}$ in $\mathrm{KCl}$ ), adjusted to a final concentration of $0.5 \%$ in Triton X-100, rehomogenized and allowed to stand for $1 \mathrm{hr}$. The suspension was sonicated extensively, dialyzed against distilled water, lyophilized, and stored at $-20^{\circ} \mathrm{C}$ until used.

Mucins were prepared as described previously (24).

Preparation of glycosyltransferase acceptors. A microsomal acceptor was prepared by heat treatment as described previously (22). The following glycoprotein acceptors were prepared. Ovine submaxillary mucin (OSM) ${ }^{2}$

${ }^{2}$ Abbreviations used in this paper: OSM, ovine submaxillary mucin; PSM, porcine submaxillary mucin; UTP, uridine triphosphate. free of carbohydrates was prepared by the removal of $N$ acetylneuraminic acid and $N$-acetyl-D-galactosamine by sequential treatment with neuraminidase (Vibrio cholerae, Calbiochem, Los Angeles, Calif.) and N-acetylhexosaminidase prepared from jack bean meal as described by $\mathrm{Ha}-$ gopian, Bosmann, and Eylar (25). Ovine submaxillary mucine was a gift of Dr. W. Pigman. Porcine submaxillary mucine (PSM) was prepared according to the method of de Salegui and Plonska (26), from pooled submaxillary glands exhibiting only human blood group O-like activity. Two acceptors were prepared from this mucin. PSM free of $\mathrm{N}$-acetylneuraminic acid was prepared by treatment with neuraminidase, heat inactivation, dialysis, and lyophilization (27). PSM free of $N$-acetylneuraminic acid and fucose was prepared by first treating the PSM with $0.05 \mathrm{~N} \mathrm{H}_{2} \mathrm{SO}_{4}$ at $85^{\circ} \mathrm{C}$ for $90 \mathrm{~min}$ and then followed by dialysis and lyophilization (28). Fetuin, free of both $\mathrm{N}$-acetylneuraminic acid and D-galactose, was prepared from fetal calf serum by the methods of Spiro $(29,30)$.

Lactose was purchased from Sigma Chemical Co., St. Louis, Mo., 2' fucosyllactose, lacto- $N$-fucopentaose I, and lacto- $N$-fucopentaose II, were generous gifts of Dr. A. Gauhe, and lacto- $N$-tetraose was kindly supplied by Dr. A. Kobata.

Analytical methods. Protein analysis was done following the method of Lowry, Rosenbrough, Farr, and Randall (31). Hexosamine contents were determined on hydrolysates (4 $\mathrm{N} \mathrm{HCl}$, at $100^{\circ} \mathrm{C}$ for $14 \mathrm{hr}$ ) by the method of Bella and Kim (32) using Beckman UR-30 resin on a Beckman 120C amino acid analyzer (Beckman Instruments, Inc., Fullerton, Calif.).

Enzyme assays. The conditions used for the assay of glycosyltransferases were similar to those reported previously (22) with slight modifications. The reactions involved in the assay of these enzymes are summarized in Fig. 1. All enzyme assays were performed under conditions in which the reaction was linear with respect to enzyme concentration and time. Unless stated otherwise, incubations were carried out at $37^{\circ} \mathrm{C}$ for $1 \mathrm{hr}$ in a shaking water bath, and were terminated by the addition of $5 \mathrm{ml}$ of ice-cold $1 \%$ phosphotungstic acid in $0.5 \mathrm{~N} \mathrm{HCl}$. Bovine serum albumin (1 mg) was added as a carrier protein, and the precipitate obtained after centrifugation at $1000 \mathrm{~g}$ for $10 \mathrm{~min}$ was washed three times with the same acid solution, dissolved in $1 \mathrm{ml}$ of NCS solubilizer (Amersham/Searle Corp., Arlington Heights, Ill.) at $50^{\circ} \mathrm{C}$, and counted. When the oligosaccharides were used as the acceptor, the reaction was stopped by the addition of $3 \mathrm{ml}$ of $50 \%$ ethanol, the tubes heated at $100^{\circ} \mathrm{C}$ for $30 \mathrm{sec}$, centrifuged, and the supernatant solution passed through a column $(9 \times 20 \mathrm{~mm})$ containing Amberlite MB-3 resin. The precipitate was washed twice with distilled water and washings also passed through the column. The combined effluent and washings were evaporated to dryness and the sample dissolved in 50 $\mu \mathrm{l}$ of $50 \%$ ethanol and applied to Whatman No. $3 \mathrm{MM}$ paper. Chromatography was carried out in a solvent system of ethylacetate-pyridine-water $(2: 1: 2, \mathrm{v} / \mathrm{v})$ for $50 \mathrm{hr}$ at $25^{\circ} \mathrm{C}$. Appropriate spots were cut out from the paper and counted. Radioactivity was measured using a scintillation spectrometer with toluene-phosphor. Values were corrected for quenching or self-absorption. Control incubations were performed in all instances in the absence of either exogenous acceptor or enzyme and the sum of the radioactivity incorporated in both controls were subtracted from the total radioactivity.

Polypeptidyl: N-acetylgalactosaminyltransferase. The incubation mixture for the assay of the polypeptidyl : N-acetyl- 
1. Polypeptidyl: $N$-acetylgalactosaminyltransferase

UDP-GalNAc + Protein $(\mathrm{OSM})^{*} \longrightarrow$ GalNAc-Protein + (UDP)

2. Galactosyltransferase

UDP-Gal + GlcNAc-glycoprotein (Fetuin) $\longrightarrow \longrightarrow$

3. Fucosyltransferase

Gal-GlcNAc-glycoprotein + (UDP)

GDP-Fuc + Gal-mucin (PSM)§ $\left.\longrightarrow\right|_{\text {Fuc }} ^{\text {Gal-mucin }+(G D P)}$

4. $N$-acetylgalactosaminyltransferase

(a) UDP-GalNAc + Gal-mucin (PSM) $\| \longrightarrow$ GalNAc-Gal-mucin + (UDP)<smiles>[TeH][TeH2]</smiles>

(b) UDP-GalNAc + Gal-Glc (2' Fucosyllactose) $\longrightarrow$

Fuc

$\underset{\text { Fuc }}{\text { GalNAc-Gal-Glc }+(\text { UDP })}$

FIGURE 1 Summary of reactions used in the assay of glycosyltransferases. Abbreviations used are: UDP-GalNAc, UDP- $N$-acetyl-D-galactosamine; UDP-Gal, UDP-D-galactose; GDP-Fuc, GDP-L-fucose; Gal, D-galactose; Glc, D-glucose; and Fuc, L-fucose.

* OSM, ovine submaxillary mucin free of carbohydrates ( $N$-acetylneuraminic acid and $N$ acetyl-D-galactosamine).

$¥$ Fetuin free of $N$-acetylneuraminic acid and D-galactose.

$\S$ PSM, porcine submaxillary mucin free of $N$-acetylneuraminic acid.

II PSM, porcine submaxillary mucin free of $N$-acetylneuraminic acid and L-fucose.

galactosaminyltransferase contained the following: 2.63 nmoles $(250,000 \mathrm{dpm})$ of UDP- $N$-acetyl-D-galactosamine$1{ }^{14} \mathrm{C}(42 \mathrm{mCi} / \mathrm{mm}$, New England Nuclear Corp., Boston, Mass.), $0.2 \mathrm{mg}$ of enzyme protein, $0.1 \mathrm{mg}$ of ovine submaxillary mucin free of $N$-acetylneuraminic acid and $N$ acetyl-D-galactosamine, $3.25 \mu$ moles of $\mathrm{MnCl}_{2}, 0.33 \mu$ moles of ATP, $0.33 \mathrm{mg}$ of Triton X-100, and $17.5 \mu$ moles of Tris-maleate, $\mathrm{pH} 6.9$ in a final volume of $0.33 \mathrm{ml}$.

$N$-acetylgalactosaminyltransferase. Conditions of assay were similar to those described for polypeptidyl : $N$-acetylgalactosaminyltransferase. The only difference was the acceptors used; either $1 \mathrm{mg}$ protein of heat-treated microsomal acceptor or $0.8 \mathrm{mg}$ of porcine submaxillary mucin free of $N$-acetylneuraminic acid. When oligosaccharides were used as acceptors, similar incubation mixture was used with $0.05 \mu$ moles of the oligosaccharide added.

$N$-acetylglucosaminyltransferase. The incubation mixture contained: 2.63 nmoles $(250,000 \mathrm{dpm})$ of UDP- $N-$ acetyl-D-glucosamine-1-14C $(43 \mathrm{mCi} / \mathrm{mm}$, New England $\mathrm{Nu}-$ clear Corp., Boston, Mass.), $0.2 \mathrm{mg}$ of enzyme protein, 1 $\mathrm{mg}$ of microsomal acceptor protein, $3.25 \mu$ moles of $\mathrm{MnCl}_{2}$, $0.33 \mu$ moles of ATP, $0.33 \mathrm{mg}$ of Triton X-100, and 175 $\mu$ moles of Tris-maleate, $\mathrm{pH} 6.9$, in a final volume of 0.33 $\mathrm{ml}$.

Galactosyltransferase assay. The incubation mixture contained the following: 0.17 nmoles $(100,000 \mathrm{dpm})$ of UDPD-galactose- ${ }^{14} \mathrm{C} \quad(298 \mathrm{mCi} / \mathrm{mm}$, New England Nuclear Corp.), $0.1 \mathrm{mg}$ of enzyme protein, either $1 \mathrm{mg}$ of microsomal acceptor protein or $1 \mathrm{mg}$ of fetuin free of $N$-acetyl- neuraminic acid and galactose, $3.25 \mu$ moles of $\mathrm{MnCl}_{2}, 0.33$ $\mu$ moles of ATP, $0.33 \mathrm{mg}$ of Triton X-100, and $17.5 \mu$ moles of Tris-maleate, $\mathrm{pH} 6.5$, in a final volume of $0.33 \mathrm{ml}$.

$\alpha(1 \rightarrow 2)$ Fucosyltransferase assay. For the assay of this enzyme, a method previously described from this laboratory was used (28). The enzyme $(0.2 \mathrm{mg}$ protein) was incubated at $20^{\circ} \mathrm{C}$ for $5 \mathrm{~min}$ in a total volume of $0.225 \mathrm{ml}$ containing 0.233 nmoles of GDP-L-fucose $-{ }^{14} \mathrm{C}(193 \mathrm{mCi} /$ mM, Amersham/Searle Corp., Arlington Heights, III.), 0.1 $\mathrm{mg}$ of porcine submaxillary mucin free of $N$-acetylneuraminic acid and $\mathrm{L}$-fucose, $10 \mu$ moles of magnesium acetate, $0.1 \mu$ mole of UTP, $0.225 \mathrm{mg}$ of Triton X-100, and 50 $\mu$ moles of cacodylate acetate buffer, $\mathrm{pH} 6.0$.

Preparation of rabbit anti-human blood group $A$ antisera. For use both in the immunoprecipitin analysis and the immunodiffusion studies, rabbit antiserum against human $\mathrm{A}$ blood group substance was prepared as follows: red cell stroma free of hemoglobin ( $2 \mathrm{mg}$ protein) prepared by the method of Dodge, Mitchell, and Hanahan (33) were injected weekly in the foot pads of New Zealand rabbits with complete Freund's adjuvant. On the 8th wk, a booster of $5 \mathrm{mg}$ of red cell stromal protein prepared in $0.02 \mathrm{M}$ Tris- $\mathrm{HCl}, \mathrm{pH} 7.5$, was injected intravenously and a week later blood was obtained by cardiac puncture from the overnight fasted rabbits. Merthiolate was added immediately to the serum $(1: 10,000) .5 \mathrm{ml}$ each of serum was then absorbed with $20 \mathrm{mg}$ dry weight of human type $O$ stroma twice by incubating the mixture first at $25^{\circ} \mathrm{C}$ for $2 \mathrm{hr}$ and then at $4^{\circ} \mathrm{C}$ for $48 \mathrm{hr}$. The mixture was centri- 
fuged at $40,000 \mathrm{~g}$ for $30 \mathrm{~min}$ and the resultant anti-A serum was stored at $-20^{\circ} \mathrm{C}$ until used.

Conversion of $A^{-}$to $A^{+}$mucin. $\mathrm{A}^{-}$mucin $(30 \mu \mathrm{g})$ was incubated with $\mathrm{A}^{+}$microsomes (1 $\mathrm{mg}$ protein) under the condition described for the $N$-acetylgalactosaminyltransferase. The incubation was for $5 \mathrm{hr}$ at $37^{\circ} \mathrm{C}$ and UDP-Nacetyl-D-galactosamine- $1-{ }^{14} \mathrm{C}$ of low specific activity $\left(1 \times 10^{\circ}\right.$ $\mathrm{dpm} / \mu$ mole) was used as a substrate in the final concentration of $1 \mathrm{~mm}$. UDP- $N$-acetyl-D-galactosamine-1-14 $\mathrm{C}$ of low specific radioactivity was prepared according to the method of Carlson, Swanson, and Roseman (34). The incubation mixture was centrifuged at $35,000 \mathrm{~g}$ for $30 \mathrm{~min}$ before samples were taken for immunochemical analysis and radioactivity measurement. Radioactivity incorporated into macromolecules was determined by precipitation with phosphotungstic acid as described for the enzyme assay.

Immunoprecipitin analysis. Portions $(50 \mu \mathrm{l})$ were taken from the above incubation mixture and transferred to a series of conical centrifuge tubes $(1 \mathrm{ml})$ containing various amounts of rabbit A antisera. The immunoprecipitin reaction was carried out in a final volume of $0.3 \mathrm{ml}$ by adding $0.9 \% \mathrm{NaCl}$ containing $0.02 \%$ sodium azide at $25^{\circ} \mathrm{C}$ for $2 \mathrm{hr}$ and $38 \mathrm{hr}$ at $4^{\circ} \mathrm{C}$ with twice daily gentle mixing. The precipitates were obtained by centrifuging the reaction mixtures at $2,000 \mathrm{~g}$ for $15 \mathrm{~min}$, and washed with ice-cold $0.9 \%$ saline until no radioactivity was extracted by the wash. The precipitates were resuspended in $1 \mathrm{ml}$ of distilled water and their radioactivity counted in a scintillation spectrometer after an addition of $10 \mathrm{ml}$ of Insta-gel (Packard Instrument Co., Inc., Downers Grove, Ill.). Control incubations were performed in the absence of the antisera and the radioactivity subtracted from the experimental values.

Immunoprecipitation inhibition. The inhibition of immunoprecipitin reaction between converted $\mathrm{A}^{+}$mucins and rabbit anti-human $A$ antisera was performed at the antisera concentration exhibiting the highest immunoprecipitating capacity. A blood group A active oligosaccharide obtained from porcine submaxillary mucin was used as inhibitor; each immunoprecipitin tube contained $400 \mu \mathrm{g}$ of the oligosaccharide. The antiserum was preincubated with the oligosaccharide for $10 \mathrm{~min}$ at $25^{\circ} \mathrm{C}$ before addition of the product of $\mathrm{A}^{-}$to $\mathrm{A}^{+}$mucin conversion. In some cases, PSM having blood group A activity was added as a carrier. The blood group A active oligosaccharide from PSM was kindly supplied by Dr. D. Carlson. The porcine submaxillary mucin having blood group A activity ( $A^{+}$PSM) was a generous gift of Dr. M. de Salegui.

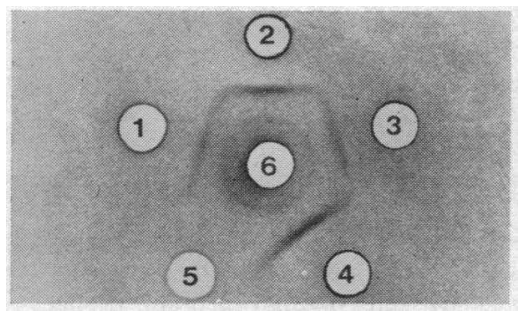

Figure 2 Double immunodiffusion of $\mathrm{A}^{+}$and $\mathrm{A}^{-}$rat mucins. The wells contained the following: 1 . Salivary mucin from human blood group $A$ secretor; $2 . \mathrm{A}^{+}$rat mucin; 3 . Extract of the intestinal mucosa from a human blood group A secretor; 4. $A^{+}$rat mucin; 5. $A^{-}$rat mucin; 6. Rabbit anti-human blood group $\mathrm{A}$ antiserum.

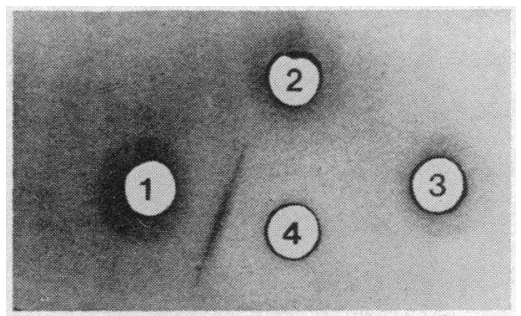

Figure 3 Double immunodiffusion of $\mathrm{A}^{+}$mucins against rabbit anti-human $A$ antiserum absorbed with blood group A substances. 1. Unabsorbed rabbit anti-human antiserum; 2. Rabbit anti-human $A$ antiserum absorbed with human $A$ secretor saliva; 3 . Rabbit anti-human $A$ antiserum absorbed with $\mathrm{A}^{+} \mathrm{PSM} ; 4 . \mathrm{A}^{+}$rat mucin.

Double immunodiffusion. Double immunodiffusion was performed by the technique of Ouchterlony (35) on immunoplates (Hyland Laboratories, Los Angeles, Calif.). Mucins prepared from $\mathrm{A}^{+}$and $\mathrm{A}^{-}$rats were tested at two concentrations. ( 1 and $2.5 \mathrm{mg} / \mathrm{ml}$ ) against the rabbit antisera. Saliva and saline extracts of intestinal mucosa from human blood type A secretors were heated at $80^{\circ} \mathrm{C}$ for 10 min. The coagulates were removed by centrifugation and the supernatant fluids were dialyzed, concentrated, and applied to the immunoplates at $6 \mathrm{mg}$ per ml. Absorption of rabbit anti-human $A$ sera by $A^{+}$PSM and salivary mucin from a human blood group A secretor was performed as follows: $0.1 \mathrm{ml}$ portions of antisera were mixed with 300 $\mu \mathrm{g}$ of either $\mathrm{A}^{+}$PSM or human salivary mucin, incubated first at $25^{\circ} \mathrm{C}$ for $2 \mathrm{hr}$ and then at $4^{\circ} \mathrm{C}$ for $24 \mathrm{hr}$. Tubes were centrifuged and the supernatant fluid applied to double immunodiffusion plates. A control of antisera plus saline was incubated and handled in the same fashion. The immunodiffusion plates were developed at room temperature for 4 days, rinsed in saline for 3 days. with two changes per day. Staining of plates was done with $0.5 \%$ amido black in $7 \%$ acetic acid for $15 \mathrm{~min}$ at $25^{\circ} \mathrm{C}$; destaining was performed with $7 \%$ acetic acid until background was clear.

Hemagglutination inhibition test. Human blood group activity in the aqueous extract of rat small intestinal mucosa was determined by the method of Bendich, Kabat, and Bezer (36). The supernatant fluid $(100 \mu \mathrm{l})$ obtained by centrifuging the rat small intestinal homogenate at $20,000 \mathrm{~g}$ as described above was preincubated for $30 \mathrm{~min}$ at $25^{\circ} \mathrm{C}$ with $50 \mu 1$ each of human anti A or B typing serum ( $\mathrm{Hy}-$ land Laboratories, Los Angeles, Calif.) at three dilutions of the antiserum above the agglutination limit. To this 50 $\mu 1$ of $5 \%$ human A or B cell suspension were added and agglutination determined by microscopy. Eel serum (Marine Biological Laboratory, Woods Hole, Mass.) and anti $\mathrm{H}$ lectin (Ulex europaeus) were used to determine human blood group $\mathrm{O}(\mathrm{H})$ activity. The specificity of these $\mathrm{H}$ specific hemaglutinins was determined using human group $A, B$, and $O$ red cells. Only group $O$ red cells were agglutinated.

Hemagglutination inhibition by converted mucins. $\mathrm{A}^{-}$ mucin was incubated with $\mathrm{A}^{+}$microsomal suspensions prepared by sonication in the absence of Triton $X-100$. The incubation mixtures and conditions were similar to those used for the immunoprecipitin analysis except for the omission of Triton $\mathrm{X}-100$. The incubation mixture was centrifuged and $50 \mu \mathrm{l}$ of the clear supernatant fluid was checked 
TABLE I

Hexosamine Content of $A^{+}$and $A^{-}$Microsomes

\begin{tabular}{ccc}
\hline Microsomes & D-Glucosamine & D-Galactosamine \\
\hline & \multicolumn{3}{c}{ umoles $/ m g$} & protein \\
$\mathrm{A}^{+}$ & $59.0 \pm 8.1$ & $29.9 \pm 1.8$ \\
$\mathrm{~A}^{-}$ & $56.1 \pm 5.9$ & $10.0 \pm 1.1$
\end{tabular}

The results represent the means \pm 1 SEM of values obtained in four separate experiments.

for blood group A activity by the hemagglutination-inhibition test as described above.

\section{RESULTS}

Antigenic properties of rat mucin. Aqueous extracts of rat intestinal mucosa were examined for their ability to inhibit human A-anti A hemagglutination. Of 68 rats thus examined, 29 inhibited hemagglutination and were designated $A$ positive $\left(A^{+}\right), 39$ failed to inhibit and were designated $A$ negative $\left(A^{-}\right)$. In contrast, when these extracts were examined for the presence of B blood group activity in a human B-anti B hemagglutination assay, all extracts possessed $B$ activity. Using both $\mathrm{H}$ specific hemagglutinin from eel serum and anti $\mathrm{H}$ lectin from Ulex europaeus, all mucosal extracts demonstrated $\mathrm{H}$ antigenic activity.

Mucins were purified from the aqueous extracts of intestinal mucosa and were examined for their antigenic properties using immunodiffusion techniques. Precipitating antiserum prepared from rabbits was used. Comparison was made between rat intestinal mucins and salivary and small intestinal mucins from a blood group A human secretor (Fig. 2). Mucins from $\mathrm{A}^{+}$rats formed a single immunoprecipitin line which fused with both of the human blood group A substances. No immunoprecipitin line was observed with the $\mathrm{A}^{-}$mucins. As shown in Fig. 3, absorption of anti-A precipitating antiserum with either human A secretor saliva or
$\mathrm{A}^{+}$PSM resulted in the abolishment of the immunoprecipitating capacity of the antiserum when tested by double immunodiffusion against $\mathrm{A}^{+}$rat intestinal mucin.

Human blood group activity of rat red blood cells. Red blood cells isolated from both $\mathrm{A}^{+}$and $\mathrm{A}^{-}$rats were agglutinated with human anti $A$ and human anti $B$ antisera. Incubation of these cells with human serum lacking anti $A$ and anti $B$ antibodies did not cause agglutination, indicating that the agglutination with anti $\mathrm{A}$ and anti $\mathrm{B}$ antisera was specific, and not due to an interspecies reaction. These cells were hemolyzed by eel serum and did not agglutinate in the presence of anti $\mathrm{H}$ lectin.

Hexosamine content of microsomes. After dialysis, hexosamine analysis of microsomes isolated from $\mathrm{A}^{+}$ and $\mathrm{A}^{-}$small intestine was carried out. Results are shown in Table $I$. The D-glucosamine content was identical in the $\mathrm{A}^{+}$and $\mathrm{A}^{-}$rats but $\mathrm{D}$-galactosamine was 3 times higher in the $\mathrm{A}^{+}$than in the $\mathrm{A}^{-}$microsomes.

Glycosyltransferase activity in $A^{+}$and $A^{-}$small insestinal mucosa. Microsomes were prepared from $\mathrm{A}^{+}$ and $\mathrm{A}^{-}$rats and their abilities to catalyze the incorporation of radioactive sugars into heat-treated microsomal acceptors were measured (Table II). The $\mathrm{A}^{+}$microsomes were 60 times more effective than the $\mathrm{A}^{-}$microsomes in facilitating the transfer of $N$-acetyl-D-galactosamine to the acceptor. No difference was observed in the incorporation of other sugars.

It has recently been established from studies on the structure and biosynthesis of rat small intestinal mucins (22) that the transfer of $N$-acetyl-D-galactosamine to heat-treated microsomal acceptors is catalyzed by at least two enzymes, an $N$-acetylgalactosaminyltransferase and a polypeptidyl: $N$-acetylgalactosaminyltransferase. The $N$-acetylgalactosaminyltransferase adds $N$ acetyl-D-galactosamine to D-galactose at the terminal end of the carbohydrate side chains forming the A antigenic determinant from blood group $\mathrm{H}$ substance. The

TABLE II

Incorporation of Sugars into Microsomal Acceptors by $A^{+}$and $A^{-}$Rats

\begin{tabular}{|c|c|c|c|}
\hline \multirow[b]{2}{*}{ Substrate } & \multicolumn{2}{|c|}{ Enzyme activity* } & \multirow{2}{*}{$\begin{array}{c}\text { Ratio } \\
\text { of enzyme } \\
\text { activity } \\
\left(\mathrm{A}^{+} / \mathrm{A}^{-}\right)\end{array}$} \\
\hline & $A^{-}$ & $\mathbf{A}^{+}$ & \\
\hline & \multicolumn{2}{|c|}{$d p m / m g$ protein per hr } & \\
\hline UDP- $N$-acetyl-D-glucosamine-1-14C & $3,322 \pm 315$ & $3,640 \pm 464$ & 1.1 \\
\hline UDP-D-galactose-14 C & $6,178 \pm 886$ & $5,068 \pm 762$ & 0.8 \\
\hline GDP-L-fucose-14 C & $42,140 \pm 5,960$ & $45,350 \pm 4,660$ & 1.1 \\
\hline UDP- $N$-acetyl-D-galactosamine-1-14C & $2,020 \pm 308$ & $121,610 \pm 16,470$ & 60.2 \\
\hline
\end{tabular}

Acceptor used was pooled heat treated microsomes from $\mathrm{A}^{+}$and $\mathrm{A}^{-}$rats.

$*$ Results shown are the means \pm 1 SEM of values obtained in six experiments. 


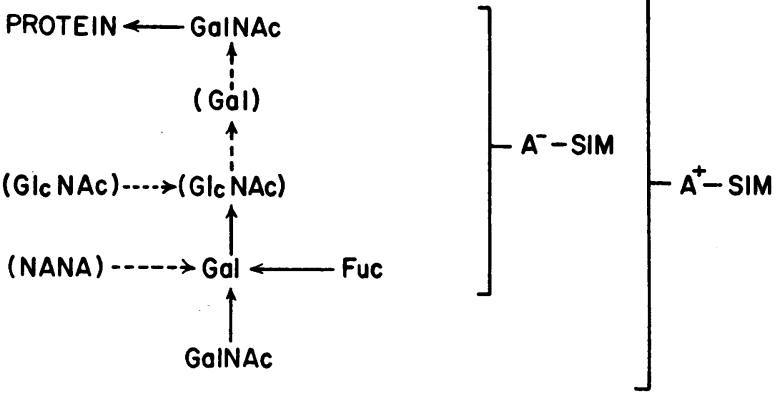

Figure 4 Proposed structures of $\mathrm{A}^{+}$and $\mathrm{A}^{-}$rat intestinal mucins. Broken lines represent possible linkages. Abbreviations used are: $\mathrm{A}^{+}-\mathrm{SIM}, \mathrm{A}^{+}$small intestinal mucins; $\mathrm{A}^{-}$SIM, $\mathrm{A}^{-}$small intestinal mucin; GalNAc, $N$-acetyl-Dgalactosamine; GlcNAc, $N$-acetyl-D-glucosamine; Gal, Dgalactose; Fuc, L-fucose; and NANA, $N$-acetylneuraminic acid.

polypeptidyl: $N$-acetylgalactosaminyltransferase catalyzed the addition of this sugar to the protein core (Figs. 1 and 4). Using heat-treated microsomal acceptors, one cannot quantitatively distinguish the activities of these two enzymes.

To distinguish between these two enzymes, therefore, specific protein acceptors of known structure were employed. As shown in Table III, the activity of the polypeptidyl $: N$-acetylgalactosaminyltransferase using a specific acceptor was the same in both $\mathrm{A}^{+}$and $\mathrm{A}^{-}$rats. However, a marked difference was noted in the activity of the $\mathrm{N}$-acetylgalactosaminyltransferase. In $\mathrm{A}^{+}$microsomes, the activity of this enzyme was over 500 times that in $\mathrm{A}^{-}$microsomes. The activities of both galactosyltransferase and fucosyltransferase were similar in both groups, as was observed previously when heat-treated microsomes were used as the acceptor.

The porcine submaxillary mucin used as an acceptor for the $N$-acetylgalactosaminyltransferase contains an $\mathrm{H}$-like blood group determinant, but may also contain other structures to which $N$-acetyl-D-galactosamine may be attached. Oligosaccharides of well-defined structure were therefore employed to determine whether the $\mathrm{H}$ determinant structure of the acceptor is required for the addition of $N$-acetyl-D-galactosamine by the enzyme present in the $\mathrm{A}^{+}$microsomes (Table IV). It can be seen that only those oligosaccharides having the $\mathrm{H}$ determinant group acted as acceptors for the $N$-acetylgalactosaminyltransferase of the $\mathrm{A}^{+}$microsomes. The $\mathrm{A}^{-}$ microsomes failed to catalyze the transfer of this sugar to any of the oligosaccharides tested.

Conversion of $A^{-}$mucin to $A^{+}$mucin. Intestinal mucins isolated from $\mathrm{A}^{+}$and $\mathrm{A}^{-}$rats were examined as acceptors for the microsomal $\mathrm{N}$-acetylgalactosaminyltransferase. As shown in Table $\mathrm{V}$, both $\mathrm{A}^{+}$and $\mathrm{A}^{-} \mathrm{mu}-$ cins acted as acceptors for the $\mathrm{A}^{+}$microsomal enzyme. The $\mathrm{A}^{-}$mucin, however, was 5 times better as an acceptor than the $\mathrm{A}^{+}$one. No radioactivity was incorporated into either mucin using the $\mathrm{A}^{-}$microsomes. In addition, heat-treated $\mathrm{A}^{-}$microsomes acted as better acceptors than $\mathrm{A}^{+}$microsomes.

To establish that the $N$-acetyl-D-galactosamine, incorporated into the $\mathrm{A}^{-}$mucin by the enzyme in the $\mathrm{A}^{+}$ microsomes, was forming the A blood group determinant, the mucin produced in the reaction was tested for A antigenic activity. Table VI shows the results of a hemagglutination inhibition study. The mixture containing the $\mathrm{A}^{-}$mucin acceptor was 4 times more effective in inhibiting human $\mathrm{A}$-anti $\mathrm{A}$ hemagglutination than were the controls.

To further substantiate that $\mathrm{A}^{-}$mucin having no blood group A activity could be converted to a mucin with an $A$ antigenic determinant by the enzyme in the $\mathrm{A}^{+}$microsomes, the product of the reaction was titrated with rabbit antihuman $A$ precipitating antiserum. The results, described in Fig. 5, showed that radioactive $\mathrm{A}^{+}$ mucin produced by the $\mathrm{A}^{+}$microsomal enzyme was precipitated by the rabbit antiserum. $30 \%$ of the radioactive product was precipitated. The addition of an oligosaccharide having blood group A activity isolated from

TABLE III

Glycosyltransferase Activity of Microsomes from Small Intestinal Mucosa of $\mathrm{A}^{+}$and $\mathrm{A}^{-}$Rats Using Specific Glycoprotein Acceptors

\begin{tabular}{|c|c|c|c|c|}
\hline \multirow[b]{2}{*}{ Glycosyltransferases } & \multirow[b]{2}{*}{ Acceptors* } & \multicolumn{2}{|c|}{ Enzyme activity $\ddagger$} & \multirow{2}{*}{$\begin{array}{c}\text { Ratio of enzyme } \\
\text { activity } \\
\left(\mathbf{A}^{+} / \mathrm{A}^{-}\right)\end{array}$} \\
\hline & & $A^{-}$ & $\mathrm{A}^{+}$ & \\
\hline & \multicolumn{4}{|c|}{$d p m / m g$ protein per $h r$} \\
\hline Galactosyltransferase & Fetuin & $116,435 \pm 18,623$ & $106,559 \pm 10,445$ & 0.9 \\
\hline$\alpha(1 \rightarrow 2)$ Fucosyltransferase & PSM & $889,070 \pm 97,274$ & $921,392 \pm 87,479$ & 1.0 \\
\hline Polypeptidyl: $N$-acetylgalactosaminyltransferase & OSM & $34,140 \pm 2,816$ & $29,470 \pm 3,342$ & 0.9 \\
\hline$N$-acetylgalactosaminyltransferase & PSM & $817 \pm 165$ & $421,514 \pm 57,484$ & 515.8 \\
\hline
\end{tabular}

* The preparation of these acceptors is described in Methods.

$\ddagger$ Results shown are the means \pm 1 SEM of values obtained in six experiments. 
TABLE IV

Acceptor Specificity of N-Acetylgalactosaminyltransferase for Human Milk Oligosaccharides

\begin{tabular}{|c|c|c|c|c|}
\hline \multirow[b]{2}{*}{ Oligosaccharide } & \multirow{2}{*}{$\begin{array}{l}\text { Blood group } \\
\text { H activity }\end{array}$} & \multirow[b]{2}{*}{ Structure } & \multicolumn{2}{|c|}{$\begin{array}{l}\text { Enzyme } \\
\text { activity* }\end{array}$} \\
\hline & & & $\mathrm{A}^{+}$ & $\mathrm{A}^{-}$ \\
\hline & & & $d_{1}$ & \\
\hline $2^{\prime}$ Fucosyllactose & + & $\underset{\alpha \prod_{\text {Fuc }}^{2} \underset{1}{\mathrm{Gal}} \stackrel{13}{\longrightarrow} \mathrm{Glc}}{\mathrm{\beta}}$ & 940 & 30 \\
\hline Lacto- $N$-fucopentaose I & + & 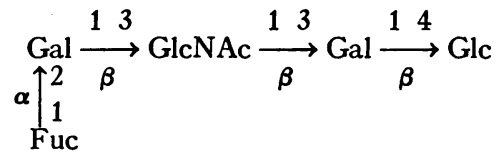 & 2160 & 37 \\
\hline Lacto- $N$-fucopentaose II & - & $\mathrm{Gal} \underset{\beta}{\stackrel{13}{\longrightarrow} \underset{\substack{4 \\
\text { Fuc }}}{\longrightarrow} \operatorname{GlcNAc}} \underset{\beta}{\stackrel{13}{\longrightarrow}} \mathrm{Gal} \underset{\beta}{\stackrel{14}{\longrightarrow}} \mathrm{Glc}$ & 0 & 0 \\
\hline Lacto- $N$-tetraose & - & $\mathrm{Gal} \underset{\beta}{\stackrel{133}{\longrightarrow}} \mathrm{GlcNAc} \underset{\beta}{\stackrel{13}{\longrightarrow}} \mathrm{Gal} \underset{\beta}{\stackrel{14}{\longrightarrow}} \mathrm{Glc}$ & 34 & 12 \\
\hline Lactose & - & $\mathrm{Gal} \underset{\beta}{\stackrel{14}{\longrightarrow}} \mathrm{Glc}$ & 0 & 0 \\
\hline
\end{tabular}

See footnotes of Fig. 1 for explanation of abbreviations.

* Means of three experiments.

$\mathrm{A}^{+}$PSM inhibited visual precipitation of this product by the rabbit antiserum. The precipitation of radioactivity by the antiserum was also inhibited by this oligosaccharide (Table VII).

\section{DISCUSSION}

The results show that red cells in all of the rats examined contained human blood group $\mathrm{A}$ and $\mathrm{B}$ antigens. All the rats were able to produce intestinal mucins having $\mathrm{B}$ and $\mathrm{H}$ antigenic activity, but $57 \%$ failed to synthesize mucins with blood group A activity. The mucins isolated from $\mathrm{A}^{+}$rats appeared to have the same antigenic structure as human blood group A substance, since they inhibited human blood group A-anti A hemagglutination, and upon immunodiffusion examination, produced a precipitin line, which fused with the human group A salivary and intestinal mucins. Furthermore this immunoprecipitin line was abolished when the antisera to human blood group A substance were pretreated with human $A$ secretor saliva, or with $A^{+}$

TABLE V

Incorporation of $N$-Acetyl-D-galactosamine into Microsomal and Mucin Acceptors Prepared from Small Intestinal Mucosa of $A^{+}$and $A^{-}$Rats*

\begin{tabular}{|c|c|c|c|c|}
\hline \multirow{2}{*}{$\begin{array}{l}\text { Enzyme activity withf } \\
\text { UDP-GalNAc-l-14-C }\end{array}$} & \multicolumn{2}{|c|}{ Microsomal acceptor } & \multicolumn{2}{|c|}{ Mucin acceptor } \\
\hline & $\mathbf{A}^{-}$ & $\mathrm{A}^{+}$ & $\mathbf{A}^{-}$ & $\mathrm{A}^{+}$ \\
\hline & \multicolumn{2}{|c|}{$d p m$} & \multicolumn{2}{|c|}{$d p m$} \\
\hline $\begin{array}{l}\mathrm{A}^{+} \text {microsomes } \\
\mathrm{A}^{-} \text {microsomes }\end{array}$ & $\begin{array}{c}12,275 \pm 1,064 \\
1,272 \pm 98\end{array}$ & $\begin{array}{l}5,642 \pm 729 \\
1,058 \pm 123\end{array}$ & $\begin{array}{c}42,197 \pm 5,144 \\
56 \pm 11\end{array}$ & $\begin{array}{c}8,485 \pm 798 \\
78 \pm 21\end{array}$ \\
\hline
\end{tabular}

Incubation mixtures contained $1 \mathrm{mg}$ each of microsomal acceptor or $30 \mu \mathrm{g}$ each of desialized small intestinal mucin.

* The results represent the means \pm 1 SEM of values obtained in six experiments. $\ddagger$ UDP-GalNAc-1-14 C, UDP- $N$-acetyl-D-galactosamine-1-14 C. 
TABLE VI

Human Blood Group A-Anti A Hemagglutination Inhibition by the Reaction Products of Incubation of $A^{-}$Mucin with $N$-Acetylgalactosaminyltransferase ( $A^{+}$Microsomes)

\begin{tabular}{lcccccc}
\hline & \multicolumn{2}{c}{ Before incubation } & & \multicolumn{2}{c}{ After incubation } \\
\cline { 2 - 3 } \multicolumn{1}{c}{ Incubation mixtures } & Titer* & $\begin{array}{c}\text { Relative blood group A } \\
\text { activity }\end{array}$ & & Titer* & $\begin{array}{c}\text { Relative blood group A } \\
\text { activity }\end{array}$ \\
\hline Complete & $1: 8$ & 1 & & $1: 2$ & 4 \\
Minus UDP-GalNAc-1-14C 8 & $1: 8$ & 1 & & $1: 8$ & 1 \\
Minus A- mucin & $1: 8$ & 1 & & $1: 8$ & 1 \\
\hline
\end{tabular}

* Titer represents the dilution of anti A serum required for hemagglutination of A red cells after incubation.

$\ddagger$ Complete incubation mixtures contained the following: $\mathrm{A}^{-}$mucin, $\mathrm{A}^{+}$microsomes, $\mathrm{UDP}-\mathrm{N}$-acetylD-galactosamine-1-14 $\mathrm{C}, \mathrm{MnCl}_{2}, \mathrm{ATP}$, and Tris-maleate buffer, $\mathrm{pH}$ 6.9. The exact amounts of each are described in Enzyme assays in methods section.

\& UDP-GalNAc-1-14 C, UDP- $N$-acetyl-D-galactosamine-1-14 $\mathrm{C}$.

PSM. Since rats with A antigen on their red cells did not necessarily have $A$ antigen in intestinal mucin, it appears that the antigenicity of the intestinal mucin need not always correspond to that of the red blood cell. This suggests that a system analogous to the secretornonsecretor relationship found in man (23) may exist in rats with respect to the secretion of $\mathrm{A}$ antigen in the intestine.

In contrast to the described variation within rat mucins, studies using indirect immunofluorescent techniques showed an antigen cross-reacting with human blood group A substance in the glandular cells of the

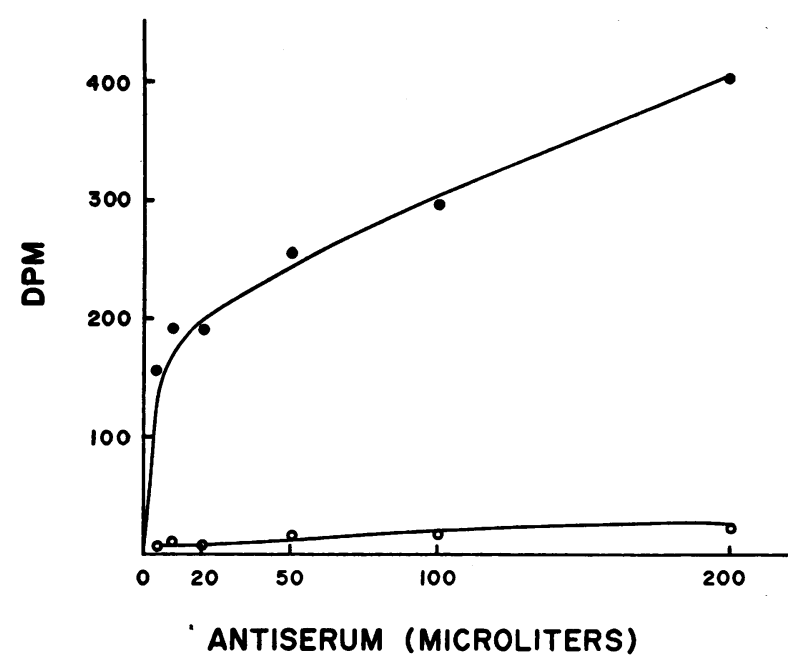

FIGURE 5 Immunoprecipitin analysis of the product of incubation of $\mathrm{A}^{-}$mucin with $\mathrm{A}^{+}$microsomes. DPM represents radioactive $N$-acetyl-D-galactosamine precipitated with rabbit antihuman A serum. $\bullet$, precipitate of products after incubation of $\mathrm{A}^{+}$microsomes with $\mathrm{A}^{-}$mucin. $\mathrm{O}$, precipitate of control incubation of $\mathrm{A}^{+}$microsomes in the absence of $\mathrm{A}^{-}$mucin. The $\mathrm{A}^{-}$mucin alone showed no visible immunoprecipitate. colon in all of the rats and monkeys examined (18). Some aqueous extracts of submaxillary glands or gastric mucosa from pigs inhibited human blood group A-anti A hemagglutination, while some did not (19-21), an observation similar to that in the present study. However, serological cross-reactivity of the red cells of these species with those of man was not examined in any of these studies. Existence of a species-specific complex blood group unique in each mammalian species has been amply documented (37-39). However, the presence of antigens similar in structure to human $A B$ antigens on the red cells of rats has not been reported.

In man, the inability to synthesize and to create $\mathrm{ABH}$ blood group substances in glandular tissues is probably due to the absence of a fucosyltransferase which is thought to be regulated by the secretor gene in the tissue $(40,41)$. The absence of this enzyme, however, does not appear to explain the difference be-

TABLE VII

Inhibition of Immunoprecipitin Reaction between Converted $A^{+}$ Mucins and Rabbit Anti-human A Antiserum by a Blood Group A Active Oligosaccharide

\begin{tabular}{lcc}
\hline \multicolumn{1}{c}{ Addition* } & $\begin{array}{c}\text { Precipitated } \\
\text { radioactivity }\end{array}$ & Inhibition \\
\hline & $d p m$ & $\%$ \\
None & 507 & - \\
$\mathrm{A}^{+}$oligosaccharide & 52 & 89.7 \\
$\mathrm{~A}^{+}$PSM $(5 \mu \mathrm{g})$ & 475 & 6.3 \\
$\mathrm{~A}^{+}$PSM $(5 \mu \mathrm{g})+\mathrm{A}^{+}$oligosaccharide & 12 & 97.6 \\
\hline
\end{tabular}

* The complete system without additions contained: $0.2 \mathrm{ml}$ of rabbit anti-human $\mathrm{A}$ antisera, $0.05 \mathrm{ml}$ of converted $\mathrm{A}^{+}$ mucin (1700 dpm), and saline containing $0.02 \%$ sodium azide to a final volume of $0.3 \mathrm{ml}$. Where indicated, $400 \mu \mathrm{g}$ of $\mathrm{A}^{+}$oligosaccharide were used. Radioactivity was measured as described in Methods. 
tween $\mathrm{A}^{+}$and $\mathrm{A}^{-}$rats, since this enzyme was active in the intestinal mucosa of all rats tested. Therefore, the possible absence of other glycosyltransferases required for mucin biosynthesis in the small intestinal mucosa was examined. Comparison of four glycosyltransferases in the intestines of $\mathrm{A}^{+}$and $\mathrm{A}^{-}$rats showed that the activities of these enzymes were the same in both groups. The enzymes examined were a polypeptidyl: $N$ acetylgalactosaminyltransferase, an $N$-acetylglucosaminyltransferase, a galactosyltransferase, and a fucosyltransferase. A fifth enzyme studied, i.e., an $N$-acetylgalactosaminyltransferase, was found to be present only in $\mathrm{A}^{+}$rats. The specificity of the enzyme was examined using various acceptors, including human milk oligosaccharides of defined structure. The results of this study indicated that this enzyme catalyzes the addition of $N$-acetyl-D-galactosamine only to those acceptors having the $\mathrm{H}$ blood group determinant structure. The specificity of this enzyme, as found in rats, appears to be the same as that reported for the human enzyme $(40,42)$.

If the only difference between $\mathrm{A}^{+}$and $\mathrm{A}^{-}$rats is due to the apparent absence of the $N$-acetylgalactosaminyltransferase, $\mathrm{A}^{-}$mucin should be converted to $\mathrm{A}^{+}$mucin by this enzyme. In support of this hypothesis, incubation of $\mathrm{A}^{-}$mucin and UDP- $N$-acetyl-D-galactosamine with microsomes prepared from the intestinal mucosa of $\mathrm{A}^{+}$rats resulted in a product which inhibited human A-anti A hemagglutinations. This product was also precipitated with rabbit antisera against human group A red cell stroma. This precipitation was prevented by the presence of an oligosaccharide having human blood group A activity.

The $\mathrm{H}$ structure has been shown to be a precursor for the $\mathrm{A}$ determinant in man $(42,43)$. The $\mathrm{H}$ activity of mucin was higher in the $\mathrm{A}^{-}$than in the $\mathrm{A}^{+}$rat. Thus it appeared that while the $\mathrm{A}^{-}$-mucin had the potential to acquire blood group A activity, the enzyme required for the final step in its synthesis, $N$-acetylgalactosaminyltransferase, was lacking or inactive in the $\mathrm{A}^{-}$rat. Although the quantities of the purified mucins available were too limited to allow a chemical comparison, the content of D-galactosamine bound to substances (presumably mucins) in the $\mathrm{A}^{+}$microsomes was considerably higher than in $\mathrm{A}^{-}$microsomes, an observation consistent with the above concept. Based on the information obtained in this study, as well as those of a previous investigation of rat intestinal mucins (24), the structure shown in Fig. 4 has been proposed for the oligosaccharide side chains of $\mathrm{A}^{+}$and $\mathrm{A}^{-}$ mucins.

The mechanism determining the synthesis of either $\mathrm{A}^{+}$or $\mathrm{A}^{-}$mucins in rats appears to be based on a system similar to, but not identical with, that found in the human secretor-nonsecretor relationship. In the case of the human nonsecretor system, $\mathrm{N}$-acetylgalactosaminyltransferase, required for the formation of the blood group A determinant, is present in the glandular tissues but this tissue is unable to form an acceptor for this enzyme, i.e., $H$ substance. This inability stems from the lack of an $\alpha(1 \rightarrow 2)$ fucosyltransferase, an enzyme essential for the completion of the $\mathrm{H}$ determinant structure $(40,41)$. In contrast, all rats produce a mucin which has the precursor $H$ structure. The "nonsecretor" rat, however, lacks the enzyme necessary for the completion of a mucin containing the A blood group determinant in glandular tissue.

Microheterogeneity of the oligosaccharide side chains of glycoproteins and mucins is well known and is thought to be due to varying degrees of completion of the oligosaccharide side chains $(44,45)$. The observation that $\mathrm{A}^{+}$mucins had slight $\mathrm{H}$ activity and had about $20 \%$ of the acceptor ability of $\mathrm{A}^{-}$mucins may be a reflection of the microheterogeneity of the rat mucin oligosaccharides.

It has been shown that $A B O$ blood group and secretor status are determined by separate gene that are responsible for the synthesis of oligosaccharide side chains with specific terminal sequences and linkages $(25,39,40,41)$. Unlike the synthesis of proteins, the assembly of carbohydrate groups on glycoproteins is not under direct genetic control. The sequence of sugars in the oligosaccharide chain depends on the presence of different glycosyltransferases which catalyze the addition of specific sugars (46); the presence or absence of these enzymes furnishes the basis of genetic regulation. Whether mucins isolated from $\mathrm{A}^{+}$or $\mathrm{A}^{-}$ rats have different biological activities or different susceptibilities to degradation awaits clarification. Possible differences between these two groups of rats in susceptibility to experimental ulcerogenesis or carcinogenesis are under investigation and clearly may carry important implications for human studies.

\section{ACKNOWLEDGMENTS}

The excellent technical assistance of Miss Judith Nordberg is greatly appreciated. We wish to thank Dr. J. Whitehead and Dr. D. McCarthy for reviewing the manuscript.

This work was supported in part by a Veterans Administration Research Grant and V. A. RE TR-48.

\section{REFERENCES}

1. Aird, I., and H. H. Benthall. 1953. Relationship between cancer of stomach and ABO blood groups. Brit. Med. J. $1: 799$.

2. Aird, I., H. H. Benthall, J. A. Mehigan, and J. A. F. Roberts. 1954. Blood groups in relation to peptic ulceration and carcinoma of colon, rectum, breast, and bronchus. Brit. Med. J. 2: 315.

3. Doll, R., H. Drane, and A. C. Newell. 1961. Secretion of blood group substances in duodenal, gastric, and 
stomal ulcer, gastric carcinoma, and diabetes mellitus. Gut. 2 : 352.

4. Hoskins, L. C., and N. Zamcheck. 1965. Studies on gastric mucus in health and disease. II. Evidence for a correlation between ABO blood group specificity, $\mathrm{ABH}(\mathrm{O})$ secretor status, and the fucose content of the glycoproteins elaborated by the gastric mucosa. Gastroenterology. 48 : 758.

5. Marcus, D. M. 1969. The ABO and Lewis blood group system. N. Engl. J. Med. 280: 994.

6. Koscielak, J., and K. Zakrzewski. 1960. Substance from erythrocytes of blood group A. Nature (London). 187: 516.

7. Hakomori, S., and R. W. Jeanloz. 1961. Isolation and characterization of glycolipids from erythrocytes of human blood A (plus) and B (plus). J. Biol. Chem. 236: 2827 .

8. Glynn, L. E., E. J. Holborow, and G. D. Johnson. 1957. Distribution of blood group substances in human gastric and duodenal mucosa. Lancet. 2: 1083.

9. Szulman, A. E. 1966. Chemistry, distribution, and function of blood group substances. Annu. Rev. Med. $17: 307$.

10. Szulman, A. E. 1960. Histological distribution of blood group substances $\mathrm{A}$ and $\mathrm{B}$ in man. J. Exp. Med. 111: 785.

11. Denborough, M. A., H. J. Downing, and M. G. McCrea. 1967. ABO system in milk and saliva. Australas. Ann. Med. $16: 320$.

12. Kabat, E. A. 1956. Blood Group Substances: Their Chemistry and Immunochemistry. Academic Press Inc., New York.

13. Morgan, W. T. J. 1963. Some observations on carbohydrate-containing components of human ovarian cyst mucin. Ann. N. Y. Acad. Sci. 106: 177.

14. Watkins, W. M. 1966. Blood-group substances. Science (Washington). $152: 172$.

15. Painter, T. J., W. M. Watkins, and W. T. J. Morgan. 1965. Serologically active fucose-containing oligosaccharides isolated from human blood-group $\mathrm{A}$ and $\mathrm{B}$ substances. Nature (London). 206: 594.

16. Lloyd, L. O., and E. A. Kabat. 1968. Immunochemical studies on blood groups. XLI. Proposed structure for carbohydrate portion of blood group $\mathrm{ABH}, \mathrm{Le}^{\mathrm{a}}$ and $\mathrm{Le}^{\mathrm{b}}$ substances. Proc. Nat. Acad. Sci. U. S. A. 61: 1470.

17. Marcus, D. M., E. A. Kavat, and G. Schiffman. 1964. Immunochemical studies on blood groups. XXXI. Destruction of blood group A activity by enzyme from Clostridium tertium which deacetylates $N$-acetylgalactosamine in intact blood group substances. Biochemistry. 3 : 437.

18. Zineibaum, A., P. Oudea, B. Halpern, and C. Veyre. 1966. Presence in colic glandular cells of various mammalian species of an antigen crossreacting with human blood group A substances. Nature (London). 209: 159.

19. Tuppy, H., and W. L. Staudenbauer. 1966. Microsomal incorporation of $N$-acetyl-D-galactosamine into blood group substance. Nature (London). 210: 316.

20. Carlson. D. M., R. N. Iyer, and J. Mayo. 1970. Carbohydrate compositions of epithelial mucins. In Blood and Tissue Antigens. D. Aminoff, editor. Academic Press Inc., New York. 229.

21. McGuire, E. J. 1970. Biosynthesis of submaxillary mucins. In Blood and Tissue Antigens. D. Aminoff, editor. Academic Press Inc., New York. 461.

22. Kim, Y. S., J. Perdomo, and J. Nordberg. 1971. Glycoprotein biosynthesis in small intestinal mucosa. I. A study of glycosyltransferases in microsomal subfractions. J. Biol. Chem. 246: 5466.

23. Race, R. R., and R. Sanger. 1962. Blood Groups in Man. Blackwell Scientific Publications, Ltd., Oxford. 4th edition.

24. Bella, A. M., and Y. S. Kim. 1970. Purification and characterization of intestinal glycoproteins. Fed. Proc. $29: 859$.

25. Hagopian, A., and H. B. Bosmann, and E. H. Eylar. 1968. Glycoprotein biosynthesis: the localization of polypeptidyl : $N$-acetylgalactosaminyl, collagen : glucosyl, and glycoprotein: galactosyl transferases in HeLa cell membrane fractions. Arch. Biochem. Biophys. 128: 387.

26. de Salegui, M., and H. Plonska. 1969. Preparation and properties of porcine submaxillary mucins. Biochim. Biophys. Acta. 129: 49.

27. Kim, Y. S., J. Perdomo, A. Bella, Jr., and J. Nordberg. 1971. $N$-acetylgalactosaminyltransferase in human serum and erythrocyte membranes. Proc. Nat. Acad. Sci. U.S.A. $69: 1753$.

28. Bella, Jr., A., and Y. S. Kim. 1971. Biosynthesis of intestinal glycoprotein: a study of an $\alpha(1 \rightarrow 2)$ fucosyltransferase in rat small intestinal mucosa. Arch. Biochem. Biophys. 147 : 753.

29. Spiro, R. G. 1960. Studies on fetuin, a glycoprotein of fetal serum. I. Isolation, chemical composition and physicochemical properties. J. Biol. Chem. 235: 2860.

30. Spiro, R. G. 1964. Periodate oxidation of the glycoprotein fetuin. J. Biol. Chem. 239: 567.

31. Lowry, O. H., N. J. Rosenbrough, A. L. Farr, and R. J. Randall. 1951. Protein measurement with the folin phenol reagent. J. Biol. Chem. 193: 265.

32. Bella, A. M., Jr., and Y. S. Kim. 1970. An improved method of separating glucosaminitol from galactosaminitol and their amino sugars on an amino acid analyzer. J. Chromatogr. 51: 314.

33. Dodge, J., C. Mitchell, and D. Hanahan. 1963. The preparation and chemical characteristics of hemoglobinfree ghosts of human erythrocytes. Arch. Biochem. Biophys. 100: 119.

34. Carlson, D. M., A. L. Swanson, and S. Roseman. 1964. Preparation of crystalline $\alpha$-D-galactosamine-1-phosphoric acid and its conversion to UDP- $N$-acetylgalactosamine. Biochemistry. 3: 402 .

35. Ouchterlony, O. 1948. In vitro method for testing the toxin-producing capacity of diphtheria bacteria. Acta Pathol. Microbiol. Scand. 25: 186.

36. Bendich, A., E. A. Kabat, and A. E. Bezer. 1947. Immunochemical studies on blood groups. V. Further characterization of blood group $\mathrm{A}$ and $\mathrm{O}$ substances from individual hog stomachs. J. Amer. Chem. Soc. 69: 2163.

37. Palm, J. 1962. Current status of blood groups in rats. Ann. N. Y. Acad. Sci. $97: 57$.

38. Andresen, E. 1962. Blood groups in pigs. Ann. N. Y. Acad. Sci. $97: 205$.

39. Franks, D. 1962. Horse blood groups and hemotylic disease of the newborn foal. Ann. N. Y. Acad. Sci. 97: 235.

40. Grollman, E. F., and V. Ginsburg. 1967. Correlation between secretor status and occurrence of $2^{2}$-fucosyllactose in human milk. Biochem. Biophys. Res. Commun. 28: 50 .

41. Shen, L., E. G. Grollman, and V. Ginsburg. 1968. Enzymatic basis for secretor status and blood group specificity in humans. Proc. Nat. Acad. Sci. U. S. A. 59: 224. 
42. Kobata, A., and V. Ginsburg. 1970. Uridine diphosphate$N$-acetyl-D-galactosamine: $\mathrm{D}$-galactose $\alpha-3-N$-acetyl-Dgalactosaminyltransferase, a product of the gene that determines blood type $\mathrm{A}$ in man. J. Biol. Chem. 245: 1484.

43. Lloyd, K. O., E. A. Kabat, and R. E. Rosenfield. 1966. Immunochemical studies on blood groups. XXXV. Activity of fucose-containing oligosaccharides isolated from blood group $A, B$, and $H$ substances by alkaline degradation. Biochemistry. 5 : 1502.

44. Cunningham, L. W. 1968. Heterogeneity of the oligosaccharide component of crystalline ovalbumin. In Bio- chemistry of Glycoproteins and Related Substances. Proceedings of the Fourth International Conference on Cystic Fibrosis of the Pancreas. S. Karger. Basel. 141.

45. Carlson, D. M. 1968. Structures and immunological properties of oligosaccharides isolated from pig submaxillary mucins. J. Biol. Chem. 243: 616.

46. Roseman, S. 1968. Biosynthesis of glycoproteins, gangliosides and related substances. In Biochemistry of Glycoproteins and Related Substances. Proceedings of the Fourth International Conference on Cystic Fibrosis of the Pancreas. S. Karger. Basel. 244. 